lot of extra work on the police; $(c)$ they did not have enough statistical knowledge; and (d) compulsion represented an infringement of individual rights.

Through the London Ambassadors and High Commissioners of the sixteen countries where seat-belt wearing is mandatory an imposing amount of data has been assembled; and at $\mathrm{Mr}$ William Rodgers's request has been sent to the appropriate quarter in the Department of Transport.

With regard to (a) I could quote, for example, the Soviet reply: "It has been confirmed that safety belts are effective in reducing the gravity of injuries in accidents at speeds below $90 \mathrm{~km} / \mathrm{h}$ provided they were used properly-that is, when there was the necessary minimum gap between the belt and the body. If the gap is increased the effectiveness of safety belts is sharply reduced. The belts also prove ineffective in the accidents occurring at speeds higher than $90 \mathrm{~km} / \mathrm{h}$. Practically all fatal accidents involving persons using safety belts occurred at speeds of $90-140 \mathrm{~km} / \mathrm{h}$. There is no record of cases when safety belts were causing injuries." The other countries agree that seat belt injury is too uncommon to be of statistical significance.

In regard to $(b)$, none of the police forces in these countries find that their work has become more onorous. To quote the Swiss Embassy, "An inquiry among competent cantonal police organisations reveals that the compulsory wearing of seat belts causes no appreciable extra work"; and Sweden says, "As to the police co-operation, the central police authorities have been much in favour of the compulsory legislation." Objection (c) can be countered by the mass of reports now at the Ministry of Transport. France's extensive official survey of its results had to be translated into English - as had the Israeli one.

It was understandable that the Lords should have viewed objection $(d)$-infringement of individual rights-with some misgiving; for like their legal counterparts they desire to uphold the principle of freedom wherever possible. And none can deny that this is something very valuable. But Dr James Cameron in his letter to Parliament brings to our attention that more than half of all male deaths in the age group 15 to 19 are due to road traffic accidents. This sombre fact must surely make the Lords think again.

We, as GPs and surgeons, are more acutely aware than any others in our community of the deep and lasting distress caused by the tragic deaths of these young people; and it is to be earnestly hoped that Parliament will take our advice.

R S Ross

\section{Lochgelly, Fife}

\section{Use of car headlamps}

SIR,-Your special correspondent (9 December, p 1619) does not, I feel, stress sufficiently the need for the use of headlamps in conditions of poor visibility. We are told that the use of the "fog code" described in the latest Highway Code could "much reduce accidents," but the point needs to be made that drivers are required by law to use headlamps or fog lamps with rear lamps when driving under conditions of seriously impaired visibility, whether due to fog, snow, rain, or smoke. This has been of particular relevance recently when drivers, in extremely poor conditions, can be fleetingly seen speeding along motorways in daytime with only sidelights lit. Similarly, drivers in urban areas seem to care little whether or not they can be clearly seen by other road users, including pedestrians.

Although headlamp dazzle worries some drivers, the possible reduction in accidents, particularly those occurring at hazardous road junctions, would surely be considerable if cars were more easily visible. This argument, of course, not only applies to conditions of poor visibility due to fog or snow, but also extends to the routine use of dipped headlamps in urban areas at night. Motorcyclists obviously appreciate the advantages of being clearly seen. Many now regularly use headlamps in al driving conditions and well-known motorcyclists have endorsed this practice.

The police are obviously at a disadvantage in enforcing any law dealing with the compulsory use of headlamps, simply because of the work involved. Publicity explaining the advantages, both to drivers and to pedestrians, of properly aligned headlamps under specific conditions in the daytime and more generally at night could be life saving.

A similar argument could be applied to publicity in favour of wearing seat belts, but if a driver chooses not to wear his seat belt then it is he who is thrown through his windscreen in the event of an accident. If he does not use his headlamps in conditions of poor visibility then other road users, possibly children, may be injured as a consequence of their lack of awareness of his approach.

DerRICK MarTin

Department of Medicine,

Withington Hospital, Manchester

\section{Shingles: a belt of roses from Hell}

SIR,-The last paragraph of the leading article on shingles (6 January, p 5) has moved me to write this letter because I have never seen real improvement in patients referred to me by neurologists or other physicians for postherpetic pain. I am quite certain, however, that patients starting treatment on the first or second day of the formation of blisters given three to five doses of 50 rads on successive days at the root ganglion or ganglia concerned do not develop postherpetic pain. Moreover, the skin condition may heal more rapidly than usual, although of this I am not certain. The field size to be used and the estimate of the position and depth for the dose to be delivered depend on the anatomy. The doses given are so small, and to such a small volume, that unwanted early or late clinical radiation effects are absent. No radiation is given to the affected skin. The important point is to give the treatment early. In many cases even without treatment of any kind no pain would develop, but to wait to see if there is postherpetic pain is to leave any treatment too late.

The reason for the effect is not established. My working hypothesis (right or wrong) was that there was an acute small round cell inflammatory reaction of the root ganglion and that the radiation caused disintegration of the lymphocytes, setting free gammaglobulins in large concentration at the site of the virus activity. If the inflammatory process is allowed to follow its natural course, scarring in the ganglion provides a permanent pathology which produces the pain.

In some way a failure of immune response seems to be the precipitating cause of shingles, as shown by its development in patients with grossly disturbed immune mechanisms mentioned in the sixth paragraph of the leading article. I have seen a patient die with purpura fulininans complicating extensive shingles due to cytotoxic drug treatment of Hodgkin's disease. Radiation in large doses to large volumes can be followed after a latent period by shingles not necessarily in the irradiated region. ${ }^{1}$ I have always been puzzled by the apparently capricious affection of one rather than another nerve, although the development of more extensive disease when the immune damage is greater suggests that the virus might be widespread even when the shingles is not.

Oxford

F ElLIS

' Ellis, F, and Stoll, B A, British Medical fournal, 1949, $2,1323$.

SIR,-I enjoyed reading your leading article on herpes zoster (6 January, p 5), and I would like to express the following points of view as an otolaryngologist.

Herpes laryngis may be associated with facial herpes, as was first noticed by McKenzie, ${ }^{1}$ and examination of the larynx is recommended in cases of head and neck zoster. ${ }^{2}$ Also, in cases of idiopathic cord palsy, especially if of recent onset, serological tests for herpes zoster may give a clue to the cause. As your article indicated, pain during the attack may be very severe and in this case carbamazepine (Tegretol) may be of help if the pains are along the trigeminal nerve. ${ }^{2}$

Although your article indicated that zoster affecting the facial nerve appears to have a good prognosis, some authorities believe that the prognosis in cases of herpes zoster is worse than in cases of Bell's palsy ${ }^{3}$; however, this point is questioned by others.

A L PAHOR

Dudley Road Hospital and Hallam

Dudley Road Birmingham

McKenzie, D, fournal of Laryngology and Otology $1915,30,339$

Pahor, A L, fournal of Laryngology and Otology, 1979 93, 93 .

- Dalton, G A, British Medical fournal, 1960, 1, 1765.

\section{Effect of once-daily atenolol on}

ambulatory blood pressure

SIR,-Dr M W Millar Craig and his colleagues (27 January, $\mathrm{p} 237$ ) provide interesting information on circadian variations of blood pressure in six patients on once-daily dosing of atenolol, obtained using intra-arterial recording. After a paper about untreated hypertensive patients ${ }^{1}$ several letters ${ }^{2-4}$ drew attention to earlier observations obtained using noninvasive methods of recording blood pressure. These results were notable for their similarity to those reported with the intra-arterial ambulatory method, ${ }^{1}$ and suggest that information obtained by non-invasive methods may contribute to understanding circadian variations.

Dr A M J Woolfson and I used non-invasive automatic blood pressure recording equipment and reported measurements of blood pressure over 24-hour periods in patients before and during hypotensive therapy with atenolol. ${ }^{5} \mathrm{An}$ effect was seen on nocturnal and early morning blood pressure, suggesting that once-daily atenolol can control nocturnal and early morning blood pressure. Only one of five 